\title{
The problem of waste in the Russian Federation
}

\author{
Kseniya Kovalenko ${ }^{1 *}$, and Nataliya Kovalenko ${ }^{1}$ \\ ${ }^{1}$ Altai State University, Barnaul, Russia Federation
}

\begin{abstract}
This article discusses the problems of environmental safety in the sphere of disposing of domestic and industrial wastes in the environment as one of the most important aspects of sustainable development of society. At present, this problem is one of the top priorities and is being solved at the world level. With the emergence of the consumer nature of society, the issue of waste disposal becomes more acute, requiring immediate solutions on a global scale. At present, the quantity and variety of solid household waste (MSW) in the countries is rapidly increasing. This is typical not only for industry, agriculture, megacities, but also for individual residents. At the beginning of 2014, the Russian Federation accumulated more than 35 billion tons of waste. The problem of garbage is not just a difficulty, but a global environmental challenge. One of the main reasons is that there are no mechanisms for regulating the market for collection and processing of solid domestic waste in Russia. We can also say that there is a shortage of specialists in this field, competent managers capable of establishing the entire chain of waste utilization. In the Russian Federation, this problem is as acute as it is throughout the world. Unauthorized landfills are one of the components of this problem. The state should pay more attention to legal regulation of this issue, engage in environmental and legal culture of citizens in order to prevent the emergence of unauthorized landfills, their prompt liquidation, and protect the constitutional rights of citizens to an environmentally safe environment.
\end{abstract}

\section{Introduction}

The share of urban population throughout the world, and in our country in particular, gradually increases. The main feature of modern cities is that they are disturbed by ecological balance. At present time in the problem of disposing of household garbage is very acute. All processes regulate the flow of substances and energy a person must take on himself.

The process of turning a modern city into an ecosystem should be carried out complex and accompanied by environmental protection of all human activities. Today, many in the world understand that the ecological situation in our planet is far from happy [1]. We see, as on the Earth year by year forests becomes less and less, and there are more deserts. There is an erosion of fertile layer of earth, the ozone layer is depleted, the number of species of plants and animals is reduced. Because of the accumulation of gases, the greenhouse effect intensifies. When on a large scale, natural resources are destroyed and depleted, when as a result of human activities, pollutants invade environment, not only the natural world suffers.

*Corresponding author: kovalenko1288@mail.ru 
People's health is also exposed to negative effects. People can not stay healthy, if they breathe poisoned air, drink unsuitable water and consume in food products containing pesticides and other harmful substances. Each depends on the state of the whole planet, including the state of the environment his environment. There is no way for anyone to avoid this deep dependence $[1,2]$.

Each of us must come to awareness and acceptance of responsibility, as for his own way of life, and for the impact that he has on the planet. The health of our planet depends on the actions of each person, in every corner of the earth. Any settlement is an artificially created and supported by man environment in which only a person can maintain cleanliness and order.

Any village, like the city, is an extremely unstable system, often completely lost the ability to self-repair under the influence of negative environmental factors of the environment. In our time, the village, the forgotten authorities, overgrown with debris and weeds is a dangerous zone for residing in it of the person. Therefore, the probability of various environmental problems is great.

The problem of pollution of streets with garbage exists in every inhabited paragraph. Most people do not like the look of abandoned bottles, beer cans, labels, packages. Weeds not only clutter the surrounding space, but also negatively affect people. Many refer to this indifferently.

Some - with sympathy, on occasion go to cleaning. Position, the official authorities' the decision in a positive way, but the problem becomes much more serious every day. Human life closely related to the emergence of products decay, food and industrial waste. Some of them must to be exposed to the correct way of processing, otherwise they can cause serious damage to the environment. In addition, the time of the disintegration of many materials goes beyond 100 years. The active pollution of the planet and the unsolved problem of garbage led to global changes - the destruction of the environment for the existence of living organisms. The export of garbage, especially from large cities, is becoming an increasing problem of our time. None of the developed and developing countries can boast of an established system of waste disposal.

Nowadays only $60 \%$ of wastes receive a second life by processing. Burning or burial is not particularly advisable, it is only complicates the already tense situation $[1,2]$.

The problem of garbage disposal concerns absolutely all types of waste: from household to chemical. Moreover, many of them have dangerous decomposition products, which significantly complicates the processing methods [1]. Rubbish, decomposing, emits alcohols and aldehydes, which then seep into the soil, residential at home and fall into the air. An already polluted environment suffers another invasion of toxic substances. And this is what happens more than once in year, and every day and in many places.

In addition, the process of decomposition of domestic and industrial waste, more often all proceeds as an isothermal reaction. The process of heat generation can be so significant. The presence of debris can trigger a fire and as a source of ignition in combination with other adverse factors.

And it is the presence of debris in the forests, on wastelands that leads to fires in the reason for arson, even sanctioned. But the burning process of a controlled very easily can develop into a fire. The cause of fires can be and the presence of clutter and debris for other reasons, even just natural character, by chance.

\section{Methods}

The current research uses the methods of observation, comparative legal studies, formal logic, description and interpretation. The goal of research is to show that the ecological problem have systemic nature and cannot be isolated from the issues of urban development, 
economics and personal intangible interests of population. The research aims at analyzing some environmental problems of our time and draw attention to them.

Environmental safety is one of the most important aspects of sustainable development of society. At present, this problem is one of the top priorities. With the emergence of the consumer nature of society, the issue of waste disposal becomes more acute, requiring immediate solutions on a global scale.

The increase in the number of domestic and industrial waste is primarily due to scientific and technological progress. So until the XX century, people used the most readily disposable products, natural resources. Since the third quarter of the 20th century, such materials have begun to appear that decomposed for decades, centuries. In addition, scientific and technological progress is a factors of increasing the population. All this led to the formation of huge territories occupied with garbage, which, undoubtedly, causes significant harm to the environment, and consequently to man.

In the Russian Federation, this problem is as acute as it is throughout the world. Unauthorized landfills are one of the components of this problem. As Denisov V.V., Kurbatova A.S. noted: "An important feature of such landfills is spatial and temporal variability, both in volume and composition ..."[3].

The problem is aggravated by the fact that there is no effective legal regulation of waste management. In general, this aspect is touched upon in the Federal Law of January 10, 2002, No. 7-FZ "On Environmental Protection" [4] (contains concepts and provisions that pertain to environmental safety in general), in Federal Law No. 89-FZ dated June 24, 1998 "On Production and Consumption Wastes" [5]. Also, waste management activities regulated by the Land Code of the Russian Federation[6], the Water Code of the Russian Federation[7], the Forest Code of the Russian Federation [8], Federal Law No. 52-FZ of 30.03.1999 "On Sanitary and Epidemiological Well-being of the Population"[9], as well as the subordinate regulatory legal acts of the Government of the Russian Federation, The Ministry of Natural Resources of the Russian Federation, the Chief State Sanitary Doctor of the Russian Federation. But with such abundance of norms, there is a shortage of necessary subordinate acts of the executive bodies, through which the general provisions would be implemented. Thus, one of the problems is the gaps in the law. As it was noted at the parliamentary hearings in the Federation Council of the Russian Federation on December 25, 2009, "The problems of regulatory and technological support for the treatment of production and consumption wastes" the Federal Law" On Production and Consumption Wastes" contains an incomplete and undisclosed conceptual apparatus"[5]. To date, some "white spots" have been exhausted, but the following international norms have not yet been enshrined in the Law: ensuring the priority of waste disposal over their disposal, the responsibility of producers for disposal and others.

The second problem is that there is no regional operator for waste disposal. This activity mainly carried out by private legal entities. In multi-apartment buildings, in large settlements, this problem solved, since such activities are coordinated: Housing Code st. 154 - payment for utilities includes fees for hot, cold water, sanitation, electricity, gas, heating. Also to the contents of the house is the collection and removal of solid and liquid household waste [10].

In the private sector, especially in rural areas, the opposite situation develops: often there are no urns, people refuse to take out garbage because of the cost of such services. For owners of apartment houses, the principle of freedom of contract is predominant, which leads to selfexport of waste and not always to specialized landfills. If there are regional operators, this problem would be exhausted.

The next aspect is connected with the liquidation of such objects. Analyzing the judicial practice, we can conclude that one of the most difficult issues is the issue of the solution of the competence: who should be engaged in liquidation? In accordance with the Federal Law "On Production and Consumption Wastes", Article 8, the organization of collection and 
removal of domestic waste and garbage belongs to the bodies of local self-government [5]. The export of industrial waste must be carried out by the enterprise itself to specialized landfills [11].

In the case of solid domestic waste, the organizer of the liquidation of an unauthorized landfill is associated with the type of land on which it is located: if the state is an organizer of local self-government, is privately owned - the owner of the site.

Thus, the state should pay more attention to the legal regulation of this issue, to engage in environmental and legal culture of citizens in order to prevent the emergence of unauthorized dumps, their prompt liquidation and to protect the constitutional rights of citizens to an environmentally safe environment.

\section{Results}

The composition and volume of household waste are extremely diverse and depend not only on the country and the terrain, but also on the season and many other factors. There are four main methods for processing solid domestic waste (MSW):

1) Reduce waste at the top of the hierarchy. Reduction is understood not only to reduce the total amount of waste, but also reduce their toxicity and other harmful properties. The reduction of waste achieved due to the reorientation of producers and consumers to products and packaging, resulting in less waste.

2) Recycling (including composting) is the second stage of the hierarchy. Secondary processing not only preserves space in landfills, but also improves the efficiency of incineration by removing non-combustible materials from the total waste stream.

3) Further on the hierarchy there are incineration of garbage and burial in polygons; burning allows you to reduce the amount of waste in 2-10 times. The Second International Conference "Alternative Sources of Energy for Large Cities" held in Moscow in 2006 stated that solid waste is a renewable and inexpensive source of energy, especially for large cities, which is confirmed by the positive experience of a number of countries [12].

In Russia, most of the waste is disposed of by burial, and these processes are usually accompanied by enormous violations of environmental requirements. Disposal of solid household waste, bypassing the law, obviously has the most negative impact on the environment. The problem raises serious social resonance: it is, in fact, one of the most global ones related to the environmental sector.

Today we should understand that the mechanisms of managing the situation are not as large as the actual problem itself. Russian territories have accumulated too much baggage of unresolved problems related to the disposal of solid waste, but there is still a way out of the situation.

The most effective method of reducing the environmental burden created by production and consumption wastes to improve the regulatory and legal regulation of activities for handling solid waste.

The regulation of waste management is directly considered only in the Federal Law "On Production and Consumption Waste". It should be recognized that the legislative base of the Russian Federation in the field of waste management is insufficient, and the Federal Law "On Production and Consumption Wastes" does not exhaust all problems related to waste[5].

Federal Law No. 458-FZ of December 29, 2014 "On Amendments to the Federal Law " On Production and Consumption Wastes", certain legislative acts of the Russian Federation and the recognition of certain legislative acts (provisions of legislative acts) of the Russian Federation as invalid. This document drastically changes the waste management system, touching upon the fundamental concepts and principles of environmental law [13].

Almost all aspects of waste management have been changed: the issues of ownership of waste, the licensing of waste management activities, the training of persons admitted to 
handling waste, and much more have been touched upon. In addition, the terminology applied in the field of waste management was subjected to changes. So, a new concept of "solid municipal waste" was introduced. Solid municipal waste (TWC) - waste generated in residential premises in the process of consumption by individuals, as well as goods that have lost their consumer properties in the process of their use by individuals in residential premises in order to meet personal and domestic needs. TCO also includes wastes generated in the course of activities of legal entities, individual entrepreneurs and similar in composition waste generated in residential premises in the process of consumption by individuals.

\section{Conclusions}

According to the envisaged changes, regional operators will be identified in the territories of the constituent entities of the Russian Federation for collecting, transporting, processing, disposing, neutralizing and disposing of TCO. The regional operator for the treatment of TCR is a legal entity that is obliged to conclude an agreement for the provision of services for the management of TCO with the owner of TKO, which are formed and the collection points of which are located in the zone of activity of the regional operator. Changes related to the treatment of TCR will take effect as early as January 1, 2016.

The problem of municipal waste can be effectively solved only with the active participation of local authorities and the local population. Since the solution is not limited to the choice and acquisition of "adequate" technology, but requires a comprehensive intervention in all - social and economic - aspects of the problem, then the authorities' participation should not be limited to the adoption of "guiding decisions".

It should also be said about the responsibility for violation of Russian legislation in the field of waste management. In accordance with Article 28 of the Federal Law "On Production and Consumption Wastes", economic entities, officials and citizens guilty of violating legislation, which resulted in harm to the environment, human health, property of legal entities and individuals provided for by this Law and other regulatory legal acts in the field of waste management, bear disciplinary, administrative, criminal, property liability in accordance with the legislation of the state and local self-government bodies. All kinds of violations are practically reflected in the Russian legislation. However, the concealment, misrepresentation or non-provision of information at the request of officials and citizens and their associations regarding the negative impact on the environment in the formation of waste or treatment with them is not mentioned in any legislative act of the Russian Federation as an offense, for example.

\section{References}

1. A.V. Tabakova. Modern World and Environmental Education. Humanities and Education, 3 pp 48-50 (2011)

2. B.V. Erofeev. Soviet Environmental Law. (Moscow, VYUZI, 1988)

3. URL:http://altkprf.ru/index.php/news/news-places/2996-deputaty-novoaltajskaneobkhodimo-vernut-650-tysyach-rublej-v-byudzhet-goroda(07.07.2018)
4. Federal
Law
"On
Environmental
Protection". http://www.consultant.ru/document/cons_doc_LAW_34823/(07.07.2018)
5. URL: http://www.consultant.ru/document/cons_doc_LAW_19109/ (07.07.2018)
6. URL: www.consultant.ru/document/cons_doc_LAW_33773/(07.07.2018)
7. URL: www.consultant.ru/document/cons_doc_LAW_60683/(07.07.2018)
8. URL:www.consultant.ru/document/cons_doc_LAW_64299/(08.07.2018) 
9. URL:www.docs.cntd.ru/document/901729631(08.07.2018)

10. K.E. Kovalenko. Some aspects of reasonableness in the law// World Applied Sciences Journal, 7 (2014)

11. URL:www.wto.org/english/thewto_e/acc_e/rus_e/WTACCRUS58_LEG_355.pdf (07.07.2018)

12. B.I. Kochurov. Geography of ecological situations (eco-diagnostics of territories). (Moscow, IG RAS, 1997)

13. URL: www.consultant.ru/document/cons_doc_LAW_172948 (07.07.2018) 